\title{
Facing a severe epidemic outbreak: a fight against arboviruses
}

After a year of the epidemic outbreak of congenital microcephaly in newborns was first detected in Pernambuco and which is a widespread around the world. However, we consider this an opportune moment to publish an issue in the Revista Brasileira de Saúde Materno Infantil/ Brazilian Journal of Maternal and Child Health specifically designed to present the results of scientific investigations carried out at the Instituto de Medicina Integral Prof. Fernando Figueira (IMIP). This is the moment in which we believe to be adequate to assess the overview of the ongoing epidemic situation along with its evolution and to have a complete understanding of the possible causes relating to the sociodemographic determinants, biological and epidemiological. Besides, clinical aspects of the problem in hospital care.

Facing this problem has been difficult, given to its complexity and the necessity of simultaneous actions in all its determinants. Clearly a wide approach could not be carried out by simply one institution. However, many scientific centers and worldwide organizations are now engaged in battling this situation. IMIP has been participating vigorously in this challenge and it can be observed in the article "Actions developed at the Instituto de Medicina Integral Prof. Fernando Figueira to confront microcephaly by Zika virus" including other more specific articles published in this special issue of the journal.

All these articles are fundamentally important because they directly address aspects in care and the best knowledge in children's clinical problems with microcephaly attended at the institution. Our intention is to present to these children and their families a great part of the clinical care activity developed at IMIP since the beginning of this worldwide phenomenon that is characterized as currently the most important epidemiological event. In fact, in the early months of 2015 in the city of Recife, the shocking situation surprised Dr. Ana van der Linden, a neurologist at IMIP along with Dr. Vanessa van der Linden of Oswaldo Cruz Hospital by perceiving a higher frequency of newborns with microcephaly and neurological disorders, soon after they suspected a possible cause and effect relation between both phenomena.1-3 Afterwards, the hypothesis of the association to microcephalic disorders with Zika virus (ZIKV) was hypothesized and the evidences were identified by Dr. Adriana Melo, in the city of Campina Grande, PB,4-6 based on the occurrence of maternal infections by ZIKV early in the pregnancy and the occurrence of microcephaly in their newborns.

These observations drew a general attention of the scientific community as well as the worldwide health authorities. The visit of the representative of the World Health Organization demonstrated the seriousness of the situation. Unfortunately until today we have not received any type of material or financial support from this institution. However, we must mention that we were praised for our competence and efficiency. Obstetricians and pediatricians were alerted that this fact was the beginning of a serious and extensive epidemiological outbreak.

After this event, there was an urgent imperative necessity to understand not only ZIKV but also other arboviruses such as dengue and chikungunya by investigating the problems in its most various dimensions.

In this special issue are included articles on arboviruses in which the titles are listed below:

Altered intrauterine ultrasound, fetal head circumference growth and neonatal outcomes among suspected cases of congenital Zika syndrome in Brazil

Epileptic seizures in children with congenital Zika virus syndrome

Presumed congenital infection by Zika virus: findings on psychomotor development - a case report 
Physiotherapeutic approach on the late phase of chikungunya: a case report

Chikungunya infection in infants

Association of arthrogryposis in neonates with microcephaly due to Zika virus - a case serie

Protocols on prenatal care for pregnant women with Zika infection and children with microcephaly: nutritional approach

Actions developed at the Instituto de Medicina Integral Prof. Fernando Figueira to confront microcephaly by Zika virus

\section{References}

1. Van der Linden V, Filho EL, Lins OG, van der Linden A, Aragão Mde F, Brainer-Lima AM, Cruz DD, Rocha MA, Sobral da Silva PF, Carvalho MD, do Amaral FJ, Gomes JA, Ribeiro de Medeiros IC, Ventura CV, Ramos RC. Congenital Zika syndrome with arthrogryposis: retrospective case series study. BMJ. 2016 Aug 9; 354: i3899.

2. Vasco Aragao MF, van der Linden V, Brainer-Lima AM, Coeli RR, Rocha MA, Sobral da Silva P, Durce Costa Gomes de Carvalho M, van der Linden A, Cesario de Holanda A, Valenca MM. Clinical features and neuroimaging (CT and MRI) findings in presumed Zika virus related congenital infection and microcephaly: retrospective case series study. BMJ. 2016 Apr 13; 353 : i1901.

3. Hazin AN, Poretti A, Turchi Martelli CM, Huisman TA; Microcephaly Epidemic Research Group, Di Cavalcanti Souza Cruz D, Tenorio M, van der Linden A, Pena LJ, Brito C, Gil LH, Barros Miranda-Filho D, Marques ET, Alves JG. Computed Tomographic Findings in Microcephaly Associated with Zika Virus. N Engl J Med. 2016 Jun 2; 374 (22): 2193-5.

4. Melo ASO, Malinger G, Ximenes R, Szejnfeld PO, Alves Sampaio S, Bispo de Filippis AM. Zika virus intrauterine infection causes fetal brain abnormality and microcephaly: tip of the iceberg? Ultrasound Obstet Gynecol. 2016; 47: 6-7.

5. Calvet G, Aguiar RS, Melo ASO, Sampaio AS, Filippis I, Fabri A, Araujo ESM, Sequeira PC, Mendonça MCL, Oliveira L, Tschoeke DA, Schrago CG, Thompson FI, Brasil P, Santos FB, Nogueira RMR, Tanuri A, Filippis AMB. Detection and sequencing of Zika vírus from amniotic fluido f fetuses with microcephaly in Brazil: a case study. Lancet Infect Dis. 2016; 16: 653-60.

6. Melo ASO, Aguiar RS, Amorim MMR, Arruda MB, Melo FO, Ribeiro STC, Batista AGM, Ferreira T, Santos MP, Sampaio VV, Moura SEM, Rabello LP, Gonzaga CE, Mallinger G, Ximenes R, Oliveira-Szejnfeld OS, Tovar-Moll F, Chimelli L, Silveira PP, Delvechio R, Higa L,Campanati L, Nogueira RMR, Filippis AMB, Szejnfeld J, Voloch CM, Ferreira Jr. OC, Brindeiro RM, Tanuri A. Congenital Zika virus infection beyond neonatal microcephaly. JAMA Neurol. 2016; Oct 3. doi: 10.1001/jamaneurol.2016.3720.

\section{Gilliatt Falbo 1}

José Eulálio Cabral Filho 2

\footnotetext{
1 President of the Instituto de Medicina Integral Prof. Fernando Figueira (IMIP). Recife, Pernambuco, Brazil.

2 Executive Editor. Revista Brasileira de Saúde Materno Infantil / Brazilian Journal of Mother and Child Health. Recife, Pernambuco, Brazil.
} 